УДК 502.1:630*43(571.16)

ОЦЕНКА ВЛИЯНИЯ ЛЕСНЫХ ПОЖАРОВ НА ЭКОЛОГИЧЕСКУЮ

ОБСТАНОВКУ И МЕРЫ ПО МОНИТОРИНГУ ЗА ЧРЕЗВЫЧАЙНЫМИ СИТУАЦИЯМИ В ЛЕСАХ ТОМСКОЙ ОБЛАСТИ

Игнатьева А.В., Кнауб Р.В., Чупина Е.А.

ФГБОУ ВО «Наииональный исследовательский Томский государственный университет», Томск, e-mail: anna_tomsktsu@mail.ru

\begin{abstract}
Ежегодно пожары в различных уголках нашей страны и за рубежом наносят значительный ущерб экологии, экономике и обществу. Для своевременного прогнозирования и снижения негативных последствий от воздействия пожаров необходимо выявлять региональную специфику возникновения пожаров, их временные рамки и силу распространения по территории. Анализ динамики пожаров, величины нанесенного ущерба территории и воздействие на экологическое состояние территории важно проводить во временной и пространственной изменчивости. В статье рассматривается пожарная обстановка, сложившаяся на территории Томской области и в ее районах. В статье проведен анализ статистических данных о пожарах, произошедших на территории Томской области, динамики пожаров и их площадей по районам области, динамики пострадавшего населения от пожаров в период с 2012 по 2018 г. На примере конкретного пожара, произошедшего 18 июля 2016 г. в Верхнекетском районе Томской области, дана оценка ущерба экологическому состоянию исследуемой территории и животному миру территории (дана характеристика выброшенных в атмосферный воздух загрязняющих веществ, характеристика погибших особей животного мира данного района и характеристика нанесенного ущерба). Представленные результаты исследования показывают, что суммарный ущерб от пожаров может достигать значительных величин в виде материального ущерба, гибели животного мира, загрязнения атмосферного воздуха и погибшего в пожаре населения. В процессе исследования было установлено, что для проведения объективного мониторинга за пожарной обстановкой, сложившейся на территории определенного района или субъекта, в Томской области необходимо наличие 1441 наблюдательного пункта.
\end{abstract}

Ключевые слова: пожары, лесные пожары, Томская область, экологические последствия пожаров, пожарные наблюдательные пункты

\title{
ASSESSMENT OF THE IMPACT OF FOREST FIRES ON THE ECOLOGICAL SITUATION AND MEASURES FOR MONITORING OF EMERGENCY SITUATIONS IN THE FORESTS OF THE TOMSK REGION
}

\author{
Ignateva A.V., Knaub R.V., Chupina E.A. \\ National Research Tomsk State University,Tomsk,e-mail: anna_tomsktsu@mail.ru
}

\begin{abstract}
Every year, fires in various parts of our country and abroad cause significant damage to the environment, the economy and society. For timely forecasting and reduction of negative consequences from the effects of fires, it is necessary to identify the regional specifics of the occurrence of fires, their time frame and the strength of spread throughout the territory. An analysis of the dynamics of fires, the magnitude of the damage caused to the territory and the impact on the ecological condition of the territory is important to carry out in temporal and spatial variability. The article discusses the fire situation prevailing in the territory of the Tomsk region. The article analyzes statistical data on fires that occurred in the Tomsk Region, the dynamics of fires and their area by region, the dynamics of the affected population from fires from 2012 to 2018. On the example of a specific fire that occurred on July 18,2016 in the Verkhneketsky district of the Tomsk Region, an assessment of the damage to the ecological state of the studied territory and the animal kingdom of the territory is given (a characteristic of pollutants thrown into the atmosphere, a characteristic of dead animals of this region and a characteristic of the damage). The presented results of the study show that the total damage from fires can reach significant values in the form of material damage, death of the animal world, air pollution and the population killed in the fire. In the course of the study, it was found that in order to conduct objective monitoring of the fire situation prevailing in the territory of a certain district or subject, the presence of 1441 observation posts in the Tomsk Region is necessary.
\end{abstract}

Keywords: fires, forest fires, Tomsk Oblast, environmental consequences of fires, fire observation posts

Природные пожары и пожары в жилом секторе оказывают разностороннее влияние на окружающую среду и климат, на жизнь, здоровье населения, наносят значительный материальный ущерб.

Пожары вызывают не только материальные потери, гибель лесов, диких и домашних животных, гибель людей. Также исследования последних лет активно указывают на наличие влияния пожаров на смертность населения от различного рода заболеваний, ухудшение общего состояния организма человека, возрастает количество обращений населения за медицинской помощью. Согласно исследованиям лаборатории экологии НИИ медицины труда и экологии (г. Чита) за два года, в период лесных пожаров в городе возросла обращаемость за скорой медицинской помощью в 3-4 раза, а смертность - в 10-13 раз [1]. Весной 
2015 г. в различных районах Сибири фиксировались масштабные пожары. Причиной большого количества пожаров становится человек, который по весне пускает палы, чтобы удалить прошлогоднюю траву. Теплая и сухая погода, ветер весной 2015 г. привели к тому, что огонь в Республике Хакасия распространялся с большой скоростью, захватывая поселения. Многолетние исследования [1] экологических и геохимических проблем лесных пожаров в различных регионах Сибири показали, что наблюдается активный вынос с дымовыми шлейфами таких опасных загрязнителей, как $\mathrm{Hg}, \mathrm{Cd}, \mathrm{Pb}, \mathrm{As}$, и искусственных радионуклидов - ${ }^{137} \mathrm{Cs},{ }^{90} \mathrm{Sr},{ }^{239},{ }^{240} \mathrm{Pu}[2]$. Приведенный набор загрязняющих веществ при попадании в организм, даже в небольших концентрациях, оказывает на него негативное влияние. Все эти компоненты в различных количествах вовлекаются в атмосферную миграцию дымовыми шлейфами лесных пожаров [1].

Актуальность исследования заключается в том, что территория Западной Сибири сосредотачивает в себе большие площади лесов, которые подвержены интенсивным лесным пожарам. В последнее время эффективность авианаблюдений за лесами в стране понижается из-за удорожания авиационных услуг. Одним из решений этой проблемы может стать разработка системы прогнозирования пожароопасной ситуации, основанной на выделении зон лесов, которым необходима охрана от пожара в первую очередь, что расширит возможности служб охраны леса в плане своевременного обна- ружения лесных пожаров и их прогнозирования [2; 3]. В данной статье будет проведен анализ пожароопасной обстановки на территории Томской области. На рис. 1 изображено территориальное расположение Томской области и соседство с другими субъектами.

В регионах в настоящее время наблюдается беспечное, а нередко хищническое отношение к лесу, которое служит причиной преднамеренных поджогов. Наиболее часто возгорания происходят в популярных местах отдыха людей, сбора дикоросов. Земли лесного фонда Томской области составляют 28,2 млн га, или 90,5\% всей ее территории. Леса области по большей части $(92 \%)$ отнесены к III группе лесов и относятся к крупной сырьевой базе лесной промышленности страны [5]. Благодаря проведению исследования было выяснено [6], что среди трех субъектов (Новосибирской, Кемеровской, Томской областей) Томская область занимает набольшую площадь лесов, но также наибольшую площадь выгоревшего лесного фонда за последние 26 лет (877 тыс. га).

Изучение пожаров, особенно их последствий, динамики за большой промежуток времени дает возможность составить прогноз на будущее для определенных территорий. Ежегодно пожары в Сибири вызывают гибель большого количества диких и домашних животных, населения, наносится значительный ущерб экономике регионов. Поэтому изучение вопросов возникновения, распространения и борьбы с пожарами является актуальным для Сибирского региона ежегодно.

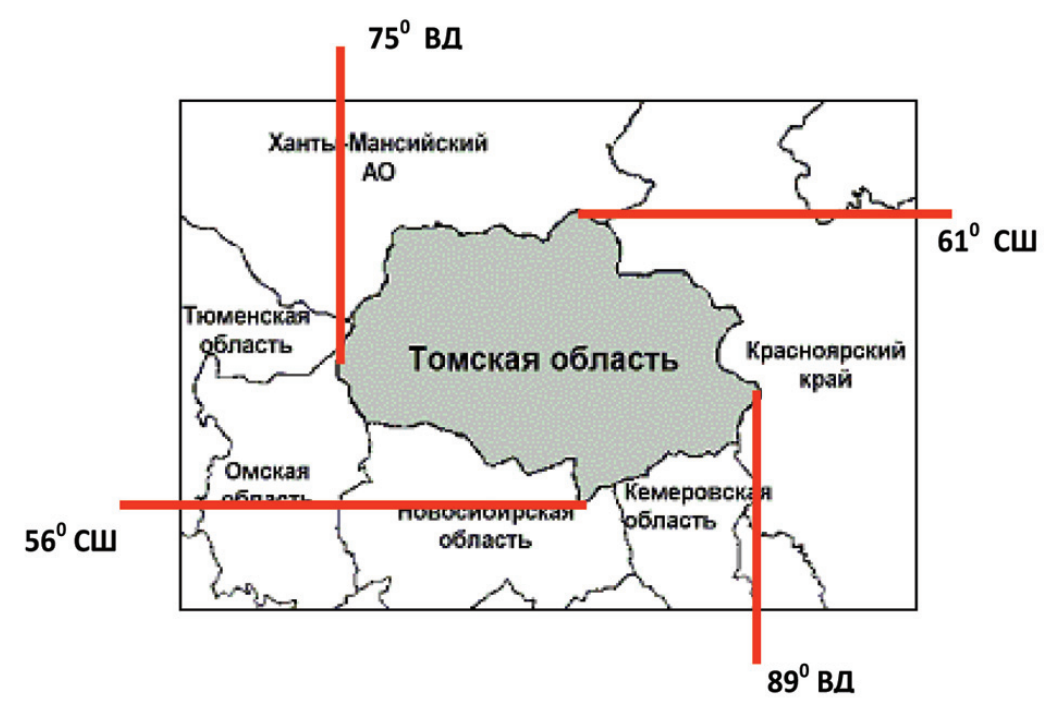

Рис. 1. Расположение Томской области в составе Сибирского федерального округа [4] 
Сильные пожары становятся причиной вынужденного перемещения животных, примером служит сильный пожар 1915 г. в Томской области, повлиявший на большую часть территории Сибири. Из-за засухи того года весенние палы не погасли, а переросли в пожары, не утихавшие все лето и охватившие пространство от 52 до $70^{\circ}$ с.ш. и от 69 до $112^{\circ}$ в.д., площадью 1,6 млн км². Местами выгорели большие пространства, например по Средней Оби и ее притокам. Общая площадь сгоревшего леса составила 1,25 млн км² [7]. Во многих местах горел торф (например, в пределах г. Томска) [8].

Последствием пожаров стало образование значительного объема дыма, который составил площадь в 6 млн км². На многих судоходных реках - Оби, Томи, Енисее и т.д. - от дыма затруднялось или приостанавливалось речное сообщение. Экспедиционные работы в крае велись с перерывами; отмечались случаи удушения охотников от дыма [8].

Эти масштабные лесные пожары повлекли за собой крупные перемещения в животном мире. Например, в Нарымском крае животные исчезли совсем в некоторых местах и появились там, где до этого не встречались [8]. Есть записи, указывающие о массовом переплывании через реки белок, медведей, змей (они переплывали Чулым, Тым и даже Обь и Енисей). При переселении многие животные заняли совсем иное местообитание [8].

Целью работы является оценка экологических последствий пожаров в лесах Томской области и мер для объективной оценки пожарной обстановки в лесах региона.

Для достижения цели были решены задачи:

1. Оценить пожарную обстановку лесов Томской области за период с 2012 по 2018 г.

2. На примере конкретного пожара оценить экологический вред территории Томской области.

3. Рассчитать для объективного мониторинга пожарной обстановки в лесах Томской области необходимое число пожарных наблюдательных пунктов.

Объектом исследования являются районы Томской области, пожары в жилом секторе Томской области и лесные пожары.

Исходя из данных статистики МЧС в Томской области, согласно средним значениям за период с 2012 по 2018 г. наибольшее число пожаров возникло в Томском районе - 54, наименьшее в Чаинском районе -1 , в г. Кедровый за период с 2012 по 2018 г. зарегистрирован всего 1 пожар. Количество пожаров по Томской области - 199 (табл. 1).

Таблица 1

Лесные пожары, зафиксированные на территории Томской области за период с 2012 по 2018 г. [5]

\begin{tabular}{|c|c|c|c|c|c|c|c|c|c|}
\hline \multirow[t]{2}{*}{ № } & \multirow[t]{2}{*}{ Район } & \multicolumn{7}{|c|}{ Зафиксированное количество лесных пожаров } & \multirow{2}{*}{$\begin{array}{l}\text { Среднее } \\
\text { значение }\end{array}$} \\
\hline & & 2012 & 2013 & 2014 & 2015 & 2016 & 2017 & 2018 & \\
\hline 1 & Александровский & 41 & 1 & 2 & 1 & 0 & 3 & 0 & 7 \\
\hline 2 & Асиновский & 17 & 1 & 1 & 8 & 9 & 3 & 1 & 6 \\
\hline 3 & Бакчарский & 13 & 0 & 0 & 1 & 10 & 0 & 0 & 3 \\
\hline 4 & Верхнекетский & 91 & 20 & 36 & 16 & 79 & 12 & 24 & 40 \\
\hline 5 & Зырянский & 16 & 0 & 5 & 5 & 4 & 0 & 0 & 4 \\
\hline 6 & Каргасокский & 106 & 8 & 2 & 3 & 15 & 9 & 2 & 21 \\
\hline 7 & Кожевниковский & 9 & 3 & 6 & 1 & 3 & 7 & 1 & 4 \\
\hline 8 & Колпашевский & 42 & 4 & 2 & 6 & 13 & 1 & 0 & 10 \\
\hline 9 & Кривошеинский & 10 & 0 & 1 & 0 & 7 & 0 & 1 & 3 \\
\hline 10 & Молчановский & 31 & 0 & 8 & 8 & 23 & 1 & 0 & 10 \\
\hline 11 & Парабельский & 15 & 3 & 4 & 6 & 15 & 14 & 13 & 10 \\
\hline 12 & Первомайский & 49 & 5 & 15 & 4 & 50 & 6 & 4 & 19 \\
\hline 13 & Тегульдетский & 12 & 0 & 1 & 0 & 3 & 0 & 0 & 2 \\
\hline 14 & Томский & 83 & 13 & 65 & 73 & 58 & 48 & 35 & 54 \\
\hline 15 & Чаинский & 0 & 0 & 5 & 0 & 0 & 0 & 0 & 5 \\
\hline 16 & Шегарский & 10 & 1 & 2 & 3 & 8 & 9 & 5 & 5 \\
\hline 17 & г. Кедровый & 0 & 0 & 0 & 1 & 0 & 0 & 0 & 1 \\
\hline 18 & г. Стрежевой & 0 & 0 & 0 & 0 & 0 & 0 & 0 & 0 \\
\hline & Итого по области & 545 & 59 & 155 & 136 & 297 & 113 & 86 & 199 \\
\hline
\end{tabular}


Информация, содержащаяся в табл. 1 и 2, получена по запросу авторов в Управлении МЧС РФ по Томской области.

По данным статистики МЧС в Томской области, по средним значениям за период c 2012 по 2018 г. наибольшая площадь лесных пожаров за пожароопасный сезон составила в Александровском районе - 10495,3 га, наименьшая по области площадь зафиксирована в г. Кедровый - 0,8 га. Общая площадь лесных пожаров в области составила 22478,3 га (табл. 2). Наибольшее число лесных пожаров возникает по вине местного населения и составляет 46 \%. Наименьшее число лесных пожаров происходит по причине сельскохозяйственных палов - 3\% и выжигания травы - 4\%. 25\% лесных пожаров возникают вследствие удара молний. У $22 \%$ лесных пожаров причина не выяснена [5].

\section{Результаты исследования и их обсуждение}

Для проведения анализа общего объема выбросов загрязняющих веществ газовой смеси от пожара масса $M_{i}$ каждого компонента аэрозоля была использована формула [9]:

$$
M i=m^{*} K a i,
$$

где $m$ - масса сгорающих растительных материалов, $K_{a i}-$ значения коэффициентов эмиссии для каждого из компонентов дымового аэрозоля из методики. Всего, согласно методике [10], при сгорании 1 кг растительных горючих материалов в атмосферу выбрасывается 135 г оксида углерода (СО), 94 г углекислого газа, 0,4 г оксида азота, 1,4 г сажи, 75 г метана.

Оценка экологических последствий от лесных пожаров Томской области показана на примере пожара в Верхнекетском районе 18 июля 2016 г.

18 июля 2016 г. в 20 часов 30 минут был обнаружен лесной пожар в Верхнекетском лесничестве Ягодинского участкового лесничества в квартале 127 в 10,7 км в направлении на северо-запад от п. Сайга. Пожар обнаружен Верхнекетским авиаотделением, с помощью космических средств обнаружения (на рис. 2 изображены очаги возгорания на 18 июля 2016 г. на территории Верхнекетского района).

Площадь пожара в момент обнаружения составила 32 га. Причина возникновения пожара - от грозы. Низовой устойчивый пожар сильной интенсивности. Общая площадь, пройденная пожаром, составила 1607 га, из них 1561,4 га насаждений, из которых возможна реализация древесины, и 45,6 га молодняков естественного происхождения.

Таблица 2

Площадь лесных пожаров в районах Томской области за период с 2012 по 2018 г. [5]

\begin{tabular}{|c|c|c|c|c|c|c|c|c|c|}
\hline \multirow[t]{2}{*}{ № } & \multirow[t]{2}{*}{ Район } & \multicolumn{7}{|c|}{ Площадь лесных пожаров, га } & \multirow{2}{*}{$\begin{array}{l}\text { Среднее } \\
\text { значение }\end{array}$} \\
\hline & & 2012 & 2013 & 2014 & 2015 & 2016 & 2017 & 2018 & \\
\hline 1 & Александровский & 73091,7 & 85 & 156,4 & 0,1 & 0 & 134 & 10495,3 & 7 \\
\hline 2 & Асиновский & 374,1 & 2,5 & 3,7 & 55,4 & 85,5 & 94,5 & 88,1 & 6 \\
\hline 3 & Бакчарский & 4683,34 & 0 & 0 & 100 & 333 & 0 & 730,9 & 3 \\
\hline 4 & Верхнекетский & 17761 & 1600,81 & 1206,78 & 419,8 & 11440,2 & 153,53 & 4703,2 & 40 \\
\hline 5 & Зырянский & 218,65 & 0 & 690,5 & 42,4 & 42,2 & 0 & 142,0 & 4 \\
\hline 6 & Каргасокский & 15598 & 161 & 1 & 8,7 & 188,8 & 193,3 & 2311,6 & 21 \\
\hline 7 & Кожевниковский & 94,5 & 7,5 & 41 & 10 & 10 & 48,05 & 31,2 & 4 \\
\hline 8 & Колпашевский & 4561,09 & 28,05 & 25,2 & 146,4 & 1141,6 & 1,5 & 843,4 & 10 \\
\hline 9 & Кривошеинский & 1886,1 & 0 & 20 & 0 & 35,8 & 0 & 278,7 & 10 \\
\hline 10 & Молчановский & 3363,3 & 0 & 67 & 438,36 & 3148,29 & 3 & 1002,9 & 10 \\
\hline 11 & Парабельский & 1291 & 26 & 130,4 & 255,1 & 152,6 & 91,2 & 281,3 & 10 \\
\hline 12 & Первомайский & 2357,3 & 201,1 & 117,7 & 34,1 & 2697,1 & 34,6 & 778,7 & 19 \\
\hline 13 & Тегульдетский & 697,6 & 0 & 43 & 0 & 34,5 & 0 & 110,7 & 2 \\
\hline 14 & Томский & 2042,48 & 51,34 & 792,18 & 587,07 & 316,21 & 207,38 & 601,4 & 54 \\
\hline 15 & Чаинский & 0 & 0 & 220,8 & 0 & 0 & 0 & 31,5 & 1 \\
\hline 16 & Шегарский & 75,4 & 9 & 49 & 35,2 & 54,9 & 56,54 & 46,6 & 5 \\
\hline 17 & г. Кедровый & 0 & 0 & 0 & 5,34 & 0 & 0 & 0,8 & 0 \\
\hline 18 & г. Стрежевой & 0 & 0 & 0 & 0 & 0 & 0 & 0 & 0 \\
\hline & Ітого по области & 128096 & 2172,3 & 3564,6 & 2137,9 & 19680,7 & 1017,6 & 679,35 & 22478,3 \\
\hline
\end{tabular}




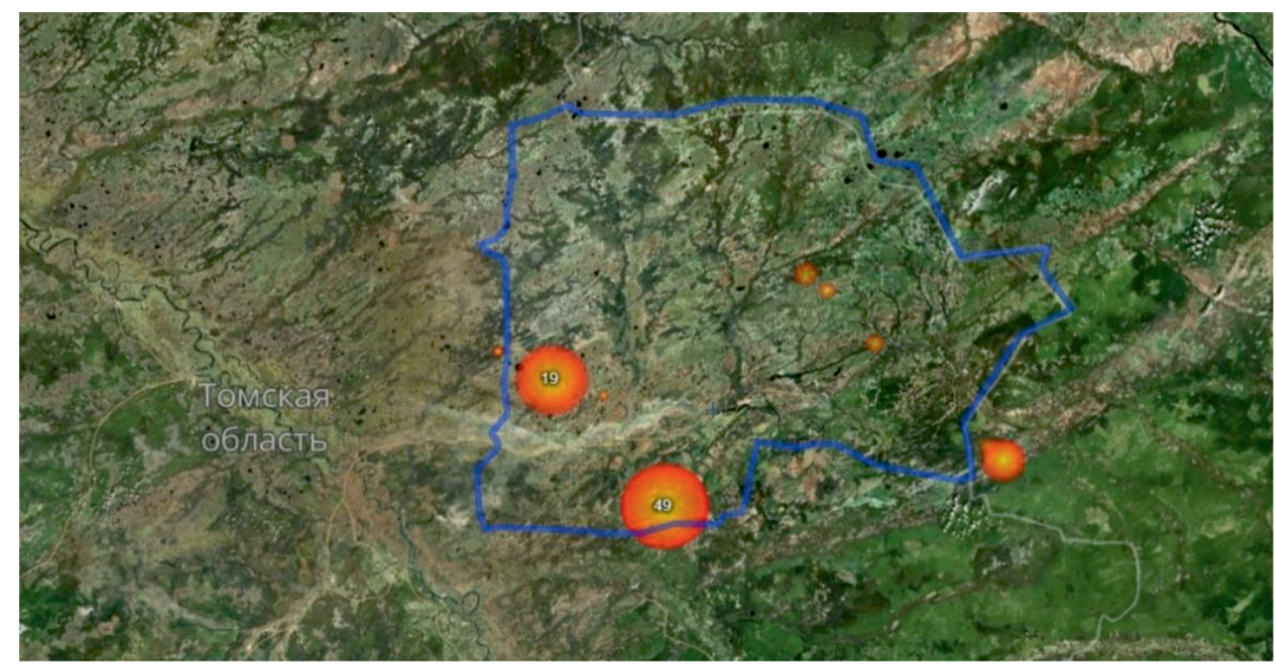

Рис. 2. Верхнекетский район с очагами возгорания на 18 июля 2016 г. [10]

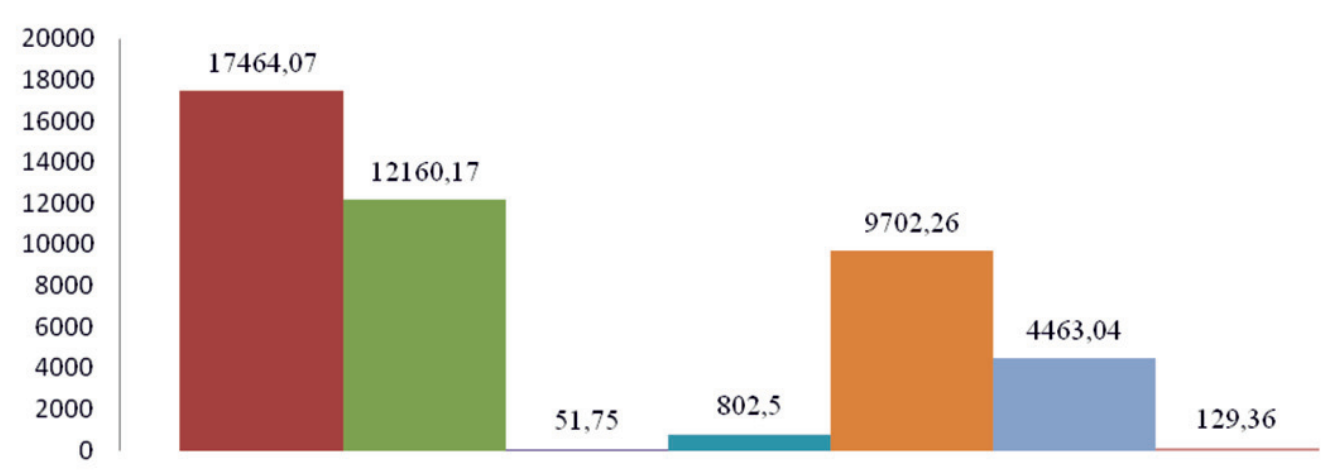

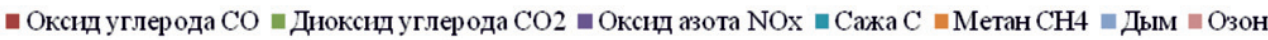

Рис. 3. Вычисленные данные о массе выбросов вредных веществ в атмосферу при пожаре 18 июля 2016 г. в Верхнекетском районе (на площади 1607 га).

Примечание: масса сгораемых органических материалов 129 363,5 m

Лесной пожар ликвидирован 19 июля 2016 г. в 21 час 30 минут, на тушение пожара было привлечено 37 АПС, 26 лесной охраны и 9 МЧС. Способы и средства по тушению пожара применялись такие, как заливание водой из лесных ранцевых опрыскивателей и прокладка минерализованных полос. В результате пожара общая сумма ущерба составила 2984 803,8 руб., из которых потери древесины на корню - 1730 457,2 руб., стоимость лесовосстановительных работ 1102872,9 руб., стоимость работ по тушению пожара составила 151 473,7 руб.

На территории преобладают сосны IV класса бонитета, средний запас эксплуатационного фонда составляет $161 \mathrm{~m}^{3} /$ га.

Объем сгорающих растительных материалов составляет $258727 \mathrm{~m}^{3}$, объем находим через произведение среднего запаса эксплуатационного фонда и площади, пройденной огнем.

Массу сгорающих растительных материалов находим через произведение объема и плотности древесины, плотность сосны составляет $500 \mathrm{\kappa г} / \mathrm{M}^{3}$. Масса сгорающих растительных материалов на площади 1607 га составляет 129363,5 т.

Рис. 3 построен согласно расчетам, произведенным авторами статьи.

В результате пожара выгорело более 129000 тонн растительных горючих материалов и в атмосферу поступило более 17000 тонн оксида углерода (СО), более 12000 тонн диоксида углерода $\left(\mathrm{CO}_{2}\right)$, более 51 тонны оксидов азота $\left(\mathrm{NO}_{x}\right)$, более 802 тонн сажи, более 9000 тонн метана, более 4000 тонн дыма (ультрадисперсные частицы $\mathrm{SiO}_{2}$ ) и более 129 тонн озона. 


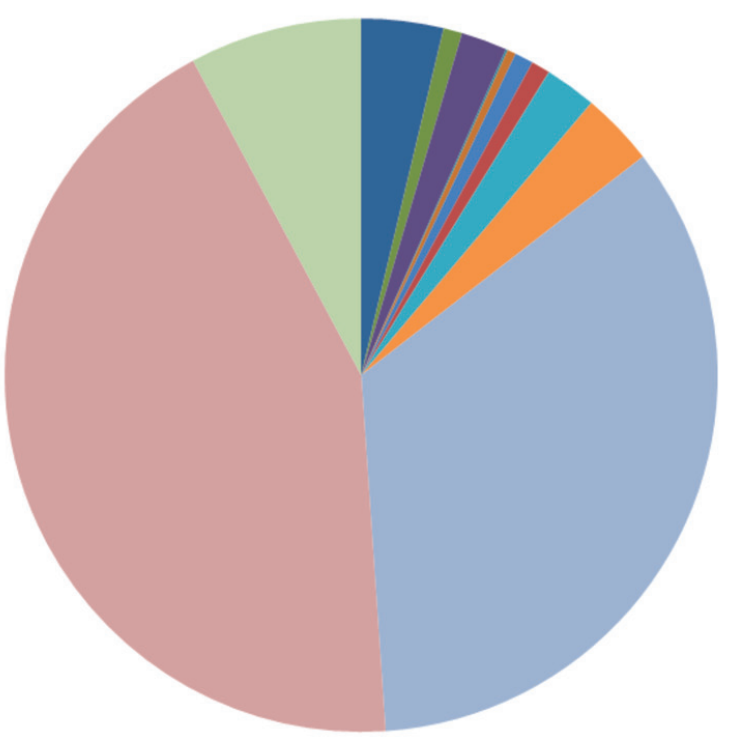
- Белка
пволк
- Горностай
- Заяц-беляк
полонок
- Лисица
п Лось
- Олень
- Pocomaxa
- Рысь
п Соболь
пГлухарь
ш Тетерев
घябчикк

Рис. 4. Плотность особей видов животных на исследуемой территории [11]

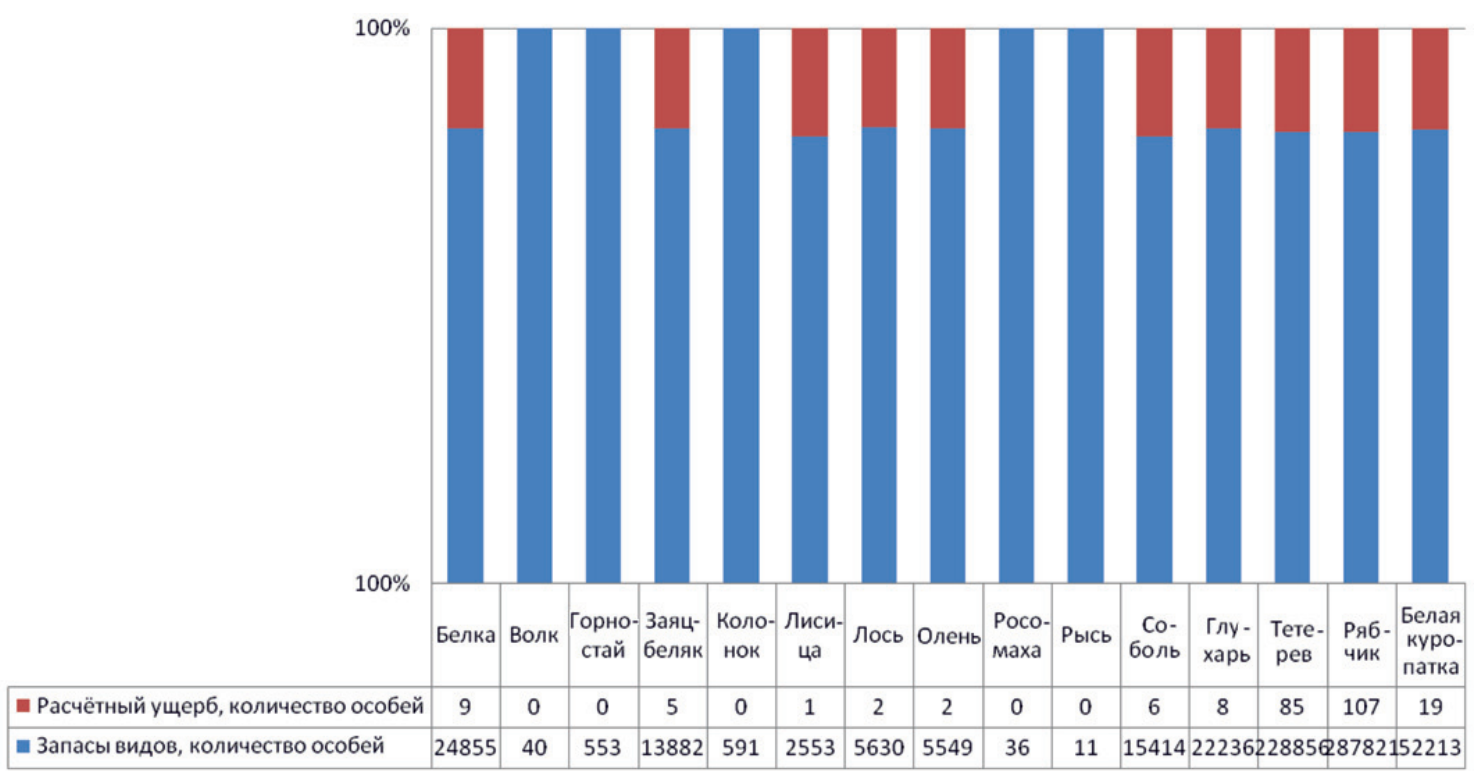

Рис. 5. Запасы видов животных и расчетный ущерб особей различных видов животных в результате пожара в Верхнекетском районе Томской области [11]

Данный пожар, помимо выбросов в атмосферу загрязняющих веществ, имел негативные последствия для животного мира территории. На рис. 4 изображена плотность особей видов животных на исследуемой территории.

Общая площадь Верхнекетского района 4334,9 тыс. га [11]. Площадь пожара 1607 га. Исходя из численности запасов видов особей животного мира и общей площади Верхнекетского района, находим плотность одной особи на один гектар. Расчётный ущерб животного мира получаем из произведения плотности особей на площадь пожара. На рис. 5 отображены результаты расчета ущерба от воздействия пожара на животный мир Верхнекетского района.

Полученные расчеты показывают негативное влияние, которое оказывают пожары на качество воздуха и животный мир территории, на примере всего лишь одного пожара. 
От пожаров в воздухе заметно возрастают концентрации загрязняющих веществ, большое выделение оксида углерода ведет к усилению парникового эффекта. Также происходит истощение озонового слоя. Лесные пожары приводят к потере лесных ресурсов, к сокращению численности особей животного мира, а может и вовсе привести к исчезновению видового состава флоры и фауны. После лесных пожаров изменяется структура и состав почвы, увеличивается содержание золы.

Расчёт пожарных наблюдательных пунктов для территории Томской области

Для того чтобы ускорить обнаружение и сократить время на тушение лесных пожаров, рассчитано рекомендованное число пожарных наблюдательных пунктов.

Формула расчёта количества пожарных наблюдательных пунктов (ПНП):

$$
\Sigma \Pi H \Pi=\mathrm{S} 1 / \mathrm{S} 2,
$$

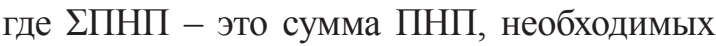
для обнаружения лесных пожаров в режиме реального времени; S1 - площадь лесного фонда региона, га; S2 - площадь наблюдения за лесом с одного ПНП, равная 20000 га.

Сумму ПНП, необходимых для обнаружения лесных пожаров в режиме реального времени, находим по формуле отношения площади лесного фонда региона к площади наблюдения за лесом с одного ПНП.

Таким образом, исходя из того что лесной фонд Томской области составляет 28,2 млн га [6], количество ПНП должно составить 1441 ПНП для своевременного обнаружения пожаров и снижения ущерба от воздействия пожаров на территорию и население. На данный момент на всей территории Томской области таких пунктов насчитывается 8 единиц.

\section{Заключение}

В заключение перечислим выводы, сформированные в результате проведения данного исследования.

1. Установлено, что максимальное количество пожаров не территории области отмечалось в 2000 г. и составило 2005 случаев, а дальше происходит постепенный спад случаев возникновения пожаров. При этом в южной части региона, где проживает около $70 \%$ населения, отмечаются максимальные суммы ущерба от пожаров. Это объясняется тем, что в радиусе 10 км от населённых пунктов происходит $81 \%$ возгораний леса.
2. В результате расчетов было установлено, что 18 июля 2016 г. в Верхнекетском районе выгорело более 129000 тонн растительных горючих материалов и в атмосферу поступило более 17000 тонн оксида углерода (СО), более 12000 тонн диоксида углерода $\left(\mathrm{CO}_{2}\right)$, более 51 тонны оксидов азота $\left(\mathrm{NO}_{\mathrm{x}}\right)$, более 802 тонн сажи, более 9000 тонн метана, более 4000 тонн дыма (ультрадисперсные частицы $\mathrm{SiO}_{2}$ ) и более 129 тонн озона.

3. По расчётным данным, ущерб видовому составу животных в результате пожара мог составить 107 рябчиков, 85 тетеревов, 19 белых куропаток, 9 белок, 8 глухарей, 6 соболей, 5 зайцев-беляков, 2 лося, 2 оленя и 1 лисица.

4. Размещение 1441 пожарного наблюдательного пункта на территории Томской области способно обеспечить природнотехносферную безопасность на территории области.

\section{Список литературы / References}

1. Щербов Б.Л., Лазарева Е.В., Журкова И.С. Лесные пожары и их последствия (на примере сибирских объектов). Новосибирск: Гео, 2015. 154 с.

Scherbov B.L., Lazareva E.V., Gurkova I.S. Forest fires and their consequences (for example, Siberian objects). Novosibirsk: Geo, 2015. 154 p. (in Russian).

2. Дюкарев А.Г. Ландшафтно-динамические аспекты таежного почвообразования в Западной Сибири. Томск: Изд. НТЛ, 2005. 284 c.

Dukarev A.G. Landscape-dynamic aspects of taiga soil formation in Western Siberia. Tomsk: Izd. NTL, 2005. 284 p. (in Russian).

3. Лесной план Томской области на 2019-2028 годы. Томск, 2018. 102 с. [Электронный ресурс]. URL: https:// deples.tomsk.gov.ru/documents/front/view/id/11898 (дата обращения: 31.03.2020).

Forest plan of the Tomsk regionon 2019-2028 years. Tomsk, 2018. 102 p. [Electronic resource]. URL: https://deples. tomsk.gov.ru/documents/front/view/id/11898 (date of access: 31.03.2020) (in Russian).

4. Паневин В.С. Леса и лесное хозяйство Томской области: учебное пособие. Томск: Изд. Томского университета, 2006. $126 \mathrm{c}$

Panevin V.S. Forests and forestry of the Tomsk region: manual. Tomsk: Izd. Tomskogo universiteta, 2006. 126 p. (in Russian).

5. Мельник М.А. Комплексная оценка потенциала лесов (на примере Томской области) // Интерэкспо ГЕО-Сибирь. 2013. Т. 3. № 4. С. 31-36.

Melnik M.A. Complex assessment of potential of the forests (for example of Tomsk oblast) // Intere'kspo GEO-Sibir. 2013. V. 3. № 4. P. 31-36 (in Russian).

6. Вышегуров С.Х., Пономаренко Н.В., Киргинцева Е.А., Долгушин Г.Н. Сравнительный анализ горимости лесов Новосибирской, Кемеровской и Томской областей за период с 1987 по 2013 г. // Вестник НГАУ. 2014. № 4. C. 23-27 (in Russian).

Vyshegurov S.Kh., Ponomarenko N.V., Kirgintseva E.A., Dolgushin G.N. Comparative analysis of forest burnability in the Novosibirsk, Kemerovo and Tomsk Regions for the period from 1987 to 2013 // Vestnik NGAU. 2014. № 4. Р. 23-27 (in Russian).

7. Структура, функционирование и эволюция системы биогеоценозов Барабы / Под ред. Р.В. Ковалева. Новосибирск: Наука, 1974. 308 с. 
Structure, functioning and evolution of the Baraba biogeocenosis system / Pod red. R.V. Kovaleva. Novosibirsk: Nauka, 1974. 308 p. (in Russian).

8. Шокин Ю.И., Махутов Н.А., Москвичев В.В. Природно-техногенная безопасность регионов Сибири: состояние проблемы и направления действий // Труды международной конференции RDAMM - 2001. 2001. Т. 6. Ч. 2. C. 427-436.

Shokin Yu.I., Makhutov N.A., Moskvichev V.V. Natural and technological safety of Siberian regions: state of the problem and direction of action // Trudy' mezhdunarodnoj konferencii RDAMM - 2001. 2001. V. 6. Is. 2. P. 427-436 (in Russian).

9. Методика определения и расчета выбросов загрязняющих веществ от лесных пожаров. Государственный комитет Российской Федерации по охране окружающей среды. [Электронный ресурс]. URL: https://pandia.ru/ text/79/451/14615.php (дата обращения: 31.03.2020).

Methodology for the determination and calculation of pollutant emissions from forest fires. State Committee of the Russian Federation for Environmental Protection. [Electronic re- source]. URL: https://pandia.ru/text/79/451/14615.php (date of access: 31.03.2020) (in Russian).

10. Спутниковая карта очагов лесных пожаров на территории России, стран СНГ, Европы и Азии с указанием даты и времени обнаружения. [Электронный ресурс]. URL: http://fires.ru/ (дата обращения: 31.03.2020).

Satellite map of forest fires in Russia, the CIS countries, Europe and Asia, indicating the date and time of detection. [Electronic resource]. URL: http://fires.ru/ (date of access: 31.03.2020) (in Russian).

11. Государственный доклад «О состоянии и охране окружающей среды Томской области в 2016 году». Департамент природных ресурсов и охраны окружающей среды Томской области, ОГБУ «Облкомприрода» / глав. ред. Ю.В. Лунева. Ижевск: ООО «Принт-2», 2017. 160 с.

State report $« O n$ the state and environmental protection of the Tomsk region in 2016» Department of Natural Resources and Environmental Protection of Tomsk Region, OGBU Oblkompriroda / glav. red. Yu.V. Luneva. Izhevsk: OOO «Print-2», 2017. 160 p. (in Russian). 